UDC 378.026.016:004

\author{
Natalia V. Kononets \\ Doctor of Pedagogical Sciences, \\ Associate Professor at the Department of Enterprise Economics and Economic Cybernetics \\ University of Ukoopspilka "Poltava University of Economics and Trade", Poltava, Ukraine \\ ORCID ID 0000-0002-4384-1198 \\ natalkapoltava7476@gmail.com
}

Svetlana I. Nestulya

$\mathrm{PhD}$ of Historical Sciences, Associate Professor at the Department of Personnel Management and Labor Economics, Director of the Educational and Scientific Institute of Leadership

University of Ukoopspilka "Poltava University of Economics and Trade", Poltava, Ukraine

ORCID ID 0000-0002-8853-4538

snestulya@gmail.com

\title{
THE IMPLEMENTATION EXPERIENCE OF STUDENTS MOBILE TRAINING IN THE FUNDAMENTALS OF LEADERSHIP AS A RESOURCE-ORIENTED FORM
}

\begin{abstract}
In the article, the authors consider mobile learning as a form of resource-based learning of university students in the study of professionally-oriented disciplines. The advantages of mobile learning are revealed: using the latest technology in training; using lightweight, compact, portable devices in training; delivering blended, resource-oriented learning; providing a quality support for training in any format; teaching students with special needs; reducing the costs of educational support; using the new ways of educational content developing; providing the continuous targeted support for the educational process; creating a fun, exciting and comfortable learning experience. The conditions necessary for organization of mobile education in the educational environment of a modern university are described: availability of mobile devices for students and teachers; access to developed electronic educational resources (electronic textbooks and manuals, educational websites, distance learning courses); organization of feedback between the teacher and the student. On the example of the discipline "Fundamentals of Leadership" at the University of Ukoopspilks "Poltava University of Economics and Trade" (PUET), Ukraine, the authors propose ways of organizing mobile learning for distance students. The developed distance course (via distance learning platform Moodle) and the electronic manual on "Fundamentals of Leadership" for mobile devices (program Dr.Explain) are offered. The opportunities and benefits of Dr.Explain program, which allows you to create e-learning manuals for mobile learning, are demonstrated. The article states that Dr.Explain is a convenient and effective tool / aid for developing a variety of electronic educational resources, ranging from electronic lectures and manuals to complete electronic courseware package and educational Internet resources. The authors emphasize that for mobile learning, it is necessary to create electronic teaching aids in the formats supported by mobile devices.
\end{abstract}

Keywords: mobile learning; resource-based learning; distance course; electronic manual; leadership; university.

\section{INTRODUCTION}

Problem statement. The orientation of Ukrainian education towards the world standards necessitates the modernization of forms, methods and means of teaching with the proper regard for the current level of development of Internet technologies and informational communication. The transition to resource-based learning is an effective solution to these problems. The positive experience of implementing resource-based learning has for a long time been used in many countries around the world: Australia, Austria, Great Britain, Ireland, Canada, China, Germany, Norway, Singapore, the USA, Taiwan, Sweden, Switzerland, Finland, as well as Ukraine (Kononets, 2013). The leading countries of the world in the 
realities of the information society focus on providing high-quality services to the population by means of technologies that guarantee the speed and efficiency of communication. The provision of mobile services in the public sector is among them. This has been an impetus for the development of mobile learning as a form of resource-based learning (RBL) for university students. RBL at higher education institutions is considered as a holistic dynamic process of organization and stimulation of students' independent cognitive activity aimed at mastering the skills in active transformation of the informational environment, which involves optimal use of consolidated personnel, material, technological, methodological, financial and informational resources by the "student-teacher-librarian" triad. One of the most promising tasks of RBL is the mobility of the educational process, which now has to become a reality at higher education institutions of Ukraine. Today, university students in Ukraine are 100\% equipped with mobile devices (smartphones, tablets, netbooks and others), which enables their use in the educational process. The use of affordable software (browsers and cloud services) will allow students to study in any convenient place and at any time. The mobility of RBL is the creation of information networks, knowledge and data bases, the development of electronic educational resources for distance learning alongside with the preservation of traditional forms of education.

\section{ANALYSIS OF THE RECENT RESEARCH}

Today, mobile learning can be considered an advanced direction for the development of distance education in the context of RBL and electronic management of the educational process. Such attention to the use of mobile communication technologies is due to the fact that their expansion significantly exceeds the pace of Internet technologies development. Various aspects of organizing mobile learning have been studied by V. Bykov, V. Kuklev, O. Semerikov, I. Son, O. Spivakovskyi, N. Rashevska, Ibrahim Suleiman, Abdel Rahman, Baiyun Chen, Ryan Seilhamer, Luke Bennett, Kristine Peters and others. Baiyun Chen, Ryan Seilhamer, Luke Bennett, Sue Bauer point out that the implementation of mobile learning through a variety of mobile devices is an effective way for school or university students to gain knowledge, to increase its volume and to develop skills and competences in acquiring information for educational purposes, as well as a peculiar form of professional training and maintaining the productivity of the educational process while a student is independent of time, place and space (Baiyun et al., 2015, Bykov, 2010).

Kristine Peters believes that mobile devices (pocket computers) provide unique educational opportunities, namely:

a) Mobility;

b) Social interactivity;

c) Context sensitivity (the ability to collect data that are unique for the real location, environment and time, and artificial data as well);

d) Connection with various devices in order to collect information and data, and networks;

e) Individuality (an individual educational trajectory on the way to gaining knowledge) (Peters, 2007).

That is why the use of mobile technologies in education is a promising trend in the activities of higher education institutions. It should be noted that the development of mobile technologies makes portable mobile devices more convenient and versatile. Mobile phones can now work as phones, calculators, organizers, calendars, cameras, Internet servers, e-mail clients, e-book readers and more. A handheld laptop can play music and audio books, play videos, run games, etc. In addition, every person today has at least one mobile phone. With the development of mobile technologies, the need for quick access to information and the 
acquisition of knowledge has increased, and so has the mobility of population. Therefore, the search for new approaches to the organization of the educational process and the creation of educational materials that would take into account preferences of modern students and information society as a whole becomes especially relevant.

The term "mobile learning" (m-learning) refers to the use of mobile and portable IT devices such as PDAs (Personal Digital Assistants), mobile phones, laptops and tablet PCs in teaching and study. Since computers and the Internet have become essential educational tools, technologies have become more portable, accessible, efficient, and easy to use, which provides opportunities for expanding participation and access to information and communication technologies, on the Internet in particular (Golitsyna, Polovnikova, 2011).

As it has been noted by I. Son, mobile learning is a natural process of transmission and perception of information that makes use of the need for computer communication, the evolution of technical means of learning and the possibilities of information and telecommunication technologies; the natural inclination of a person is directed at what needs to be studied (Son, 2013).

V. Kuklev interprets mobile learning as e-learning via mobile devices, independent of time and space, using specialized software on a pedagogical basis of interdisciplinary and modular approaches (Kuklev, 2010).

Ibrahim Suleiman, Abdel Rahman argue that mobile learning is a kind of a creative learning strategy that focuses on the possibility of modern smartphones, tablets, laptops to become full-featured assistants for students when they need it (Suleiman, Rahman, 2014).

O. Spivakovskyi emphasizes that mobile learning is an innovative educational approach, on the basis of which a new learning environment is created at higher education institutions, where students can access educational materials at any time and in any place, which makes the process of learning more attractive, democratic, comfortable and stimulates students to self-education and life-long learning (Spivakovskyi et al., 2010).

$\mathrm{N}$. Rashevska argues that mobile learning is one of the new directions for the development of distance learning. At the same time, the means of mobile educational ICTs can be applied not only in mobile and distance learning. Thus, being by its nature the teaching software that is oriented towards the centralized storage and distributed presentation of teaching techniques, distance and mobile learning support systems can be used as mobile teaching software to support classroom learning. The researcher points out:

Mobile ICTs are a set of mobile hardware and software, as well as a system of methods and forms for using such means in the learning process in order to obtain, store, process and reproduce audio, video, text, graphic and multimedia data in terms of operational communication with global and local resources.

Mobile teaching software isthe software to support and develop the learning process, aimed at organizing students' independent work and the teacher's activities, the accessibility of which is determined by the hardware of mobile ICTs (Rashevska, 2011).

Mobile learning is a type of distance learning and the ability to receive or provide educational content on personal mobile devices (smartphones, tablets, ebooks, mobile phones, etc.). Educational content refers to digital learning assets that include any form of content or media available on a personal mobile device (Nail, Ammar, 2017).

The aim of the article is to reveal the experience of implementing students' mobile learning in the case of teaching "Fundamentals of Leadership" at the Poltava University of Economics and Trade, Ukraine. 


\section{FINDINGS}

In our research, mobile learning as a form of RBL is a system of organizational and didactic measures based on the use of mobile information and communication technologies and mobile teaching programme measures, aimed at the realization of the education content at a certain academic level according to the state standards of education.

Mobile learning as a form of RBL is closely connected with electronic and distance learning, the distinction being the emphasis on the use of mobile devices. The process of learning takes place regardless of the location and with the use of portable technologies. In other words, mobile learning reduces the location limitations in the process of getting education due to the use of portable devices.

Mobile learning implies the emergence of a whole range of new learning and teaching methods based on the assumption that the interaction in the context of the traditional classroom is often not as effective as it is expected to be. Mobile learning can be considered to be "subversive" learning that changes the paradigm" especially when its focus is shifted to learning outside the institution or to overcoming shortcomings of the existing syllabi and methods for assessing their efficiency.

That is the reason why such a wide range of opportunities was not left unattended by scholars and teaching specialists when drawing up a new "Law of Ukraine on Higher Education" (2014, № 1556-VII) that presupposes an increase in the mobility of students and teachers.

Usually, smartphones and tablets are used for mobile learning, but on the whole, other devices are also appropriate: iPads, laptops and netbooks, digital players, portable media players iPod, iPod Touch and others.

Mobile learning has an important advantage - a student can study literally anywhere at any time: on a bus, train or plane, on a beach or picnic, or even being stuck in an elevator. The main thing is to have a telephone or a tablet, the Internet is desirable but not obligatory, because mobile learning can be carried out offline.

The list of advantages of mobile learning:

- using the latest technology in training.

- using lightweight, compact, portable devices in training.

- delivering blended, resource-oriented learning.

- providing a quality support for training in any format.

- teaching students with special needs.

- reducing the costs of educational support.

- using the new ways of educational content developing.

- providing the continuous targeted support for the educational process.

- creating a fun, exciting and comfortable learning experience.

However, there are certain disadvantages that, in our opinion, are easily eliminated:

Technical problems: small size screens and keys on mobile devices; problems with the Internet access; the fact that mobile devices are battery powered; the capacity of memory available on mobile devices; information security issues; lack of consistent standards in relation to mobile platforms, device characteristics; the need to adjust usual electronic content to mobile devices; the risks associated with the loss of a mobile device.

Social and educational problems: not all students can afford a suitable mobile device; problems with assessing the learning progress; problems connected with the security of educational content; too rapid development of mobile technology; crude teaching theory for mobile learning; conceptual differences between e-learning and mobile learning; problems related to the security of personal information; the need for constant updates. 
Taking into account all the advantages and disadvantages, we have made an attempt to organize mobile learning for the PUET students in the course "Fundamentals of Leadership".

In order to organize mobile learning at university, the following conditions (minimum required) must be fulfilled:

1. mobile devices must be available for students and teachers;

2. developed electronic educational resources (electronic textbooks and manuals, educational websites, distance learning courses) must be available;

3 . feedback between a teacher and a student must be organized.

The analysis of the possibilities for introducing mobile learning has shown that students and teachers are 100\% equipped with mobile devices (implementation of Condition 1).

The second requirement has been met by developing a distance-learning course "Fundamentals of Leadership" and the electronic manual "Fundamentals of Leadership" for mobile devices. The didactic characteristics formulated by V. Lapinskyi were taken into account when developing them at the design and creation stages:

- sensory (direct) perception, which is realized through the visual representation of the objects under study;

- rational perception (mediated), which is provided by bringing the educational material to the student via oral and written speech, verbal and character-symbol descriptions of processes, phenomena and objects with their properties specified;

- awareness that involves the ability to distinguish individual parts in a whole and explain the elementary external connections between them;

- comprehension (synthesis of knowledge), which involves the ability to disclose the essence of phenomena and processes of the existing reality and understanding of the integral theory of the knowledge system;

- creative problem solving by the student who will use the distance course;

- memorization, which is stimulated by the use of rational methods of learning the teaching material, rules of memorization, methods of reinforcement and revision;

- generalization and systematization, which is embodied in the ability to group (classify) objects and phenomena by certain features and display a system of knowledge.

Today, a wide range of software tools is offered for the development of distance courses that enable the implementation of distance learning and the creation of the learning environment of an open university (Blackboard Learn, WebCT, eFront, SharePoint LMS).

Their common feature is that they allow you to track the learning process of users, store their characteristics, calculate the number of activities on certain sections of the site, as well as determine the time spent by a student to pass a certain part of the course. These systems allow users to register for the course. All information about current events and required reporting is automatically sent to the registered users. Students can be organized into groups. In addition, there is an opportunity for knowledge testing and online communication. But the main disadvantages are: cost of the system, cost of its implementation, development and maintenance of the courses. Many Ukrainian educational institutions cannot afford such courses. For example, a 12-month license for Blackboard Learn is about \$38000.

Analyzing the various platforms for creating a system of continuing education for primary school teachers, we have found that a number of Ukrainian universities use Moodle. As a result of analysis and comparison of the above platforms, based on pedagogical, didactic, organizational, technological, financial features of distance education, we came to the conclusion that students' distance education system can be organized using the Moodle platform. 
Moodle is a software suite for creating distance learning courses and websites that works with open source IMS and SCORM. Moodle can be installed on any computer that supports Hypertext Preprocessor and DBMS MySQL, PostgreSQL, Microsoft SQL Server.

Thus, we chose the distance education platform Moodle in order to create our distance course "Fundamentals of Leadership". Moodle is a free, open (Open Source) learning management system. It implements the philosophy of "pedagogy of social constructivism" and focuses on organizing the interaction between a teacher and students, although it is also suitable for organizing traditional distance courses, as well as for the support of classroom learning. With the help of such a system, you can create e-learning courses, carry out both classroom and distance learning. This software product is designed according to the standards of information education systems and meets the following characteristics: interoperability, reusability, adaptability, durability, availability, cost-effectiveness. Teachers can make extensive use of Moodle to create distance courses, download files and create lessons, hold forums and chats, give tests and conduct exams, change teaching materials quickly and easily, set time limits for tasks, etc.

In order to access the distance course "Fundamentals of Leadership", a student has to be registered and $\log$ in to the Main Center for Distance Learning of the PUET, Ukraine, at the following address: http://el.puet.edu.ua/.

With the aim of helping students and teachers, detailed guidelines on the work with Moodle system have been developed: http://el.puet.edu.ua/sites/default/files/instr_teacher.pdf.

The home page of the course "Fundamentals of Leadership" in Moodle is presented in Figure 1.

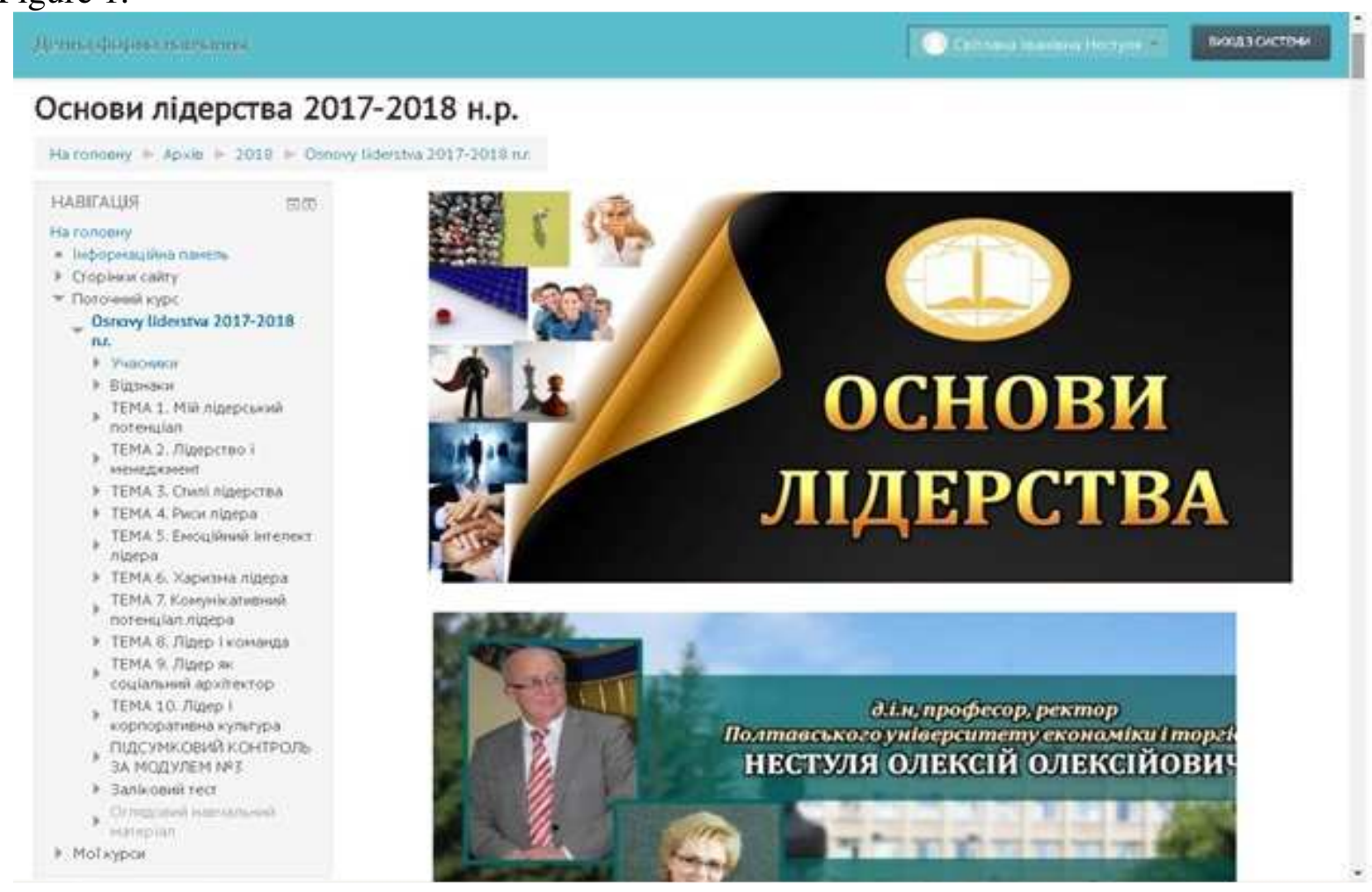

\section{Fig. 1. The Home Page of the Distance Course "Fundamentals of Leadership"}

As you can see in Figure 1, the navigation of the distance learning course is realized with the help of the navigation bar located on the left. The structure of the distance course "Fundamentals of Leadership", which reflects its content and is accessible through the navigation panel, is made up of the organizational (introductory) block of the distance course (Introduction, Guidelines on the Course, Criteria for Assessing Students' Learning Progress, 
List of Problems for Final Test, Term-paper Topics, Blog, News, Glossary, Personalities) and module blocks: Module 1 (Topics 1-4), Module 2 (Topics 5-7), Module 3 (Topics 8-10).

Defending the position of Ukrainian didactician V. Bondar (Bondar, 2005) that a didactic unit is the smallest part of the educational information that has to be perceived, analysed and learned by students, we will consider the didactic units of the distance course module as an example: Guidelines on the Module, Topic № 1. (Structure), Guidelines on the Topic, Reference Summary on Topic 1, Teaching Materials on Topic 1, Graphic Schematic Summary on Topic 1, References on Topic 1, Practical Tasks on Topic 1, Testing on Topic 1, Samples of Students' Works, To Be Studied, To Be Read (Fragments on Topic 1).

The totality of the didactic units forms the general content of the course "Fundamentals of Leadership" according to the syllabus. We will now analyse the content of the distance course modules.

Thus, the content of the distance course "Fundamentals of Leadership" reflected in the three modules is directly aimed at forming the leadership competency of the students in the process of studying the discipline (Nestulia, Nestulia, 2009).

It should be emphasized that the distance course created in Moodle implements the principle of hypertext of educational content (the ability to view the teaching materials by following hyperlinks) (Lapinskyi, 2004). Such hyperlinks in the text of the teaching materials can be found throughout the course.

Based on the research of N. Kononets and taking into account the presentation analysis of the distance course educational content developed in Moodle, we can argue that the hypertext character of the course is determined by the following characteristics: nonlinearity (the choice of arbitrary and convenient navigation in the distance course); consistency (the use of hyperlinks, navigation panels and interactive buttons as a means of linking educational content); structuring (the construction of the distance course in the form of a tree-like structure and the convenient location of the teaching material on its pages, which facilitates the process of drawing up the distance course as a hypertext environment); heterogeneous connections (due to the use of hyperlinks in the distance course, text fragments are associated with audio, video files, graphics-with presentations, etc.); meaningful completeness (linking of all the necessary components of the distance course into an integral inextricable system) (Kononets, 2016).

Undeniably, the open space of a distance course presupposes relevant roles for its users: the administrator makes any changes to the distance learning environment and is responsible for the proper functioning of the distance course, its settings and correctness of the data on the website, as well as the registration of users; tutor-teachers are teachers, managers, entrepreneurs, businessmen, leaders of local self-government, who can be involved in teaching the discipline of "Fundamentals of Leadership" with the right of access to the distance course; students studying the "Fundamentals of Leadership" discipline.

Hence, the developed distance course "Fundamentals of Leadership" is a powerful didactic resource for the formation of students' leadership competences in the university environment, which includes: means of studying the theoretical foundations of the discipline (the information component); means of supporting practical classes, doing term papers, projects, individual tasks (the practice oriented component); means of knowledge assessment (the assessment component); means of interaction of the tandem "student-teacher" (the interactive component); methodological guidelines on the study of both the whole discipline and its modules (the methodological component); means of managing the process of studying the discipline (the management component).

In order to create the electronic manual on "Fundamentals of Leadership" for mobile devices, we used Dr.Explain software to create help files, helpdesks, on-line user guides, manuals, and technical documentation for software and technical systems. As practice shows, 
Dr.Explain can be applied comfortably to create CHM reference files, print documents, ebooks, which enables its use to create hypertext electronic educational resources as well. The electronic educational resources created in this program can be stored in two formats (PDF and HTML), which solves the problem of their use on various types of modern computer equipment completely: on computers, laptops, netbooks, Apple tablet computers, smartphones, iPhones and others (Kononets, 2014).

The capture of the software interface images, editing and formatting of screenshots made, the use of visual effects and styles, etc. are among the special features of Dr.Explain. The technology of interface analysis and shot capturing enables automatic analysis of the software interface, snapshots of all controls, including buttons, menus, lists and editable areas, and then arrangement of the explanatory footnotes to the images in the project. The built-in annotation editor allows you to add a description to screenshots, use text formatting tools, insert, for example, an arrow in the right place and so on. In addition, the software allows you to remove any piece of text from where it can be removed using the copy and paste commands. Dr.Explain supports the production of documentation based on a single project in such formats as HTML (on-line guidance), CHM (help files for MS Windows), RTF and PDF with content and links.

The main benefits of Dr.Explain for a teacher-developer of electronic manuals:

- The tool integrated into Dr.Explain that captures and analyses the structure of software windows, which makes it possible to analyse the user interface of applications and create screenshots (copies of screens) of windows, automatically placing explanatory footnotes for the elements of the interface on them.

- The image annotation editor which gives an opportunity to quickly create explanatory footnotes in illustrations and screenshots.

- The specialized text editor with a wide range of functions.

- The possibility of flexible content management with the use of text variables and HTML code inserts.

- The ability to quickly update illustrations and screenshots when a new version of a software product is released. Dr.Explain allows replacing application screens saving all meta-information: footnotes, annotations, descriptions.

- The support for Help IDs in order to create context-sensitive help in applications.

- The ability to add search and indexing features to on-line help without programming (PHP, ASP, etc.) or server-side databases.

- The visual monitoring of the status of the project with the use of the status mechanism.

As it can be seen, the possibilities of Dr.Explain have proved to be very convenient and effective for the development of a variety of electronic educational resources, ranging from electronic lectures and manuals to complete electronic courseware packages of disciplines and educational Internet resources.

Figure 2 demonstrates the electronic manual on the "Fundamentals of Leadership", which is a hypertext environment for the PDF file. The navigation bar, hyperlinks, automated content are used to navigate through it, and scroll bars to view the pages. The structure of the electronic manual "Fundamentals of Leadership" consists of: the front page, the content, foreword, 10 topics, practical classes, trainings, research topics, methods of learning intensification, the list of references. These pages are displayed in the navigation bar on the left - this is the first level. The second level is the pages of additional materials for studying the topic (graphical and schematic summary, the practical task, guidelines and the test), which can be displayed in the panel by pressing the "+" button (Fig. 2). 


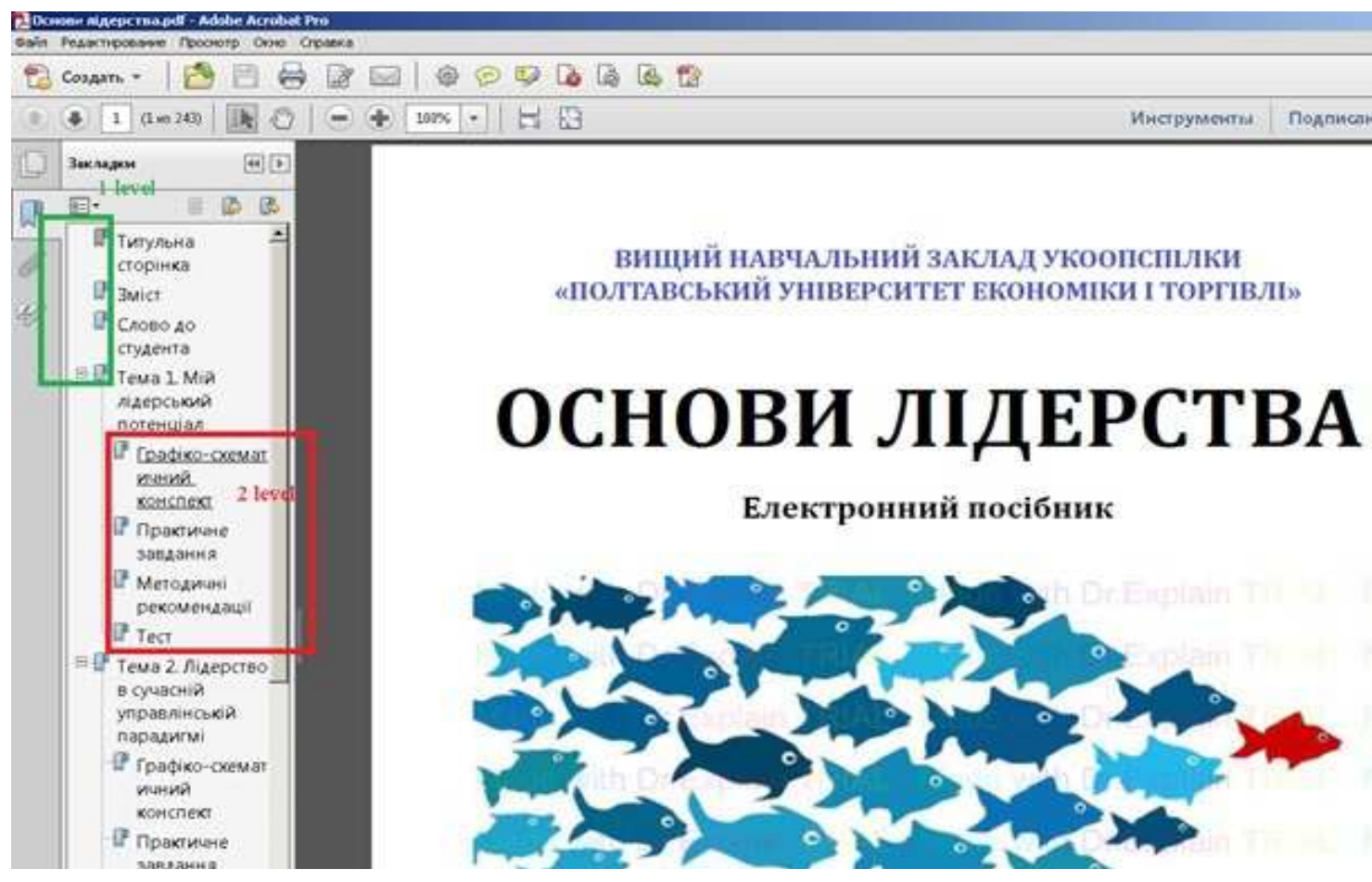

Fig. 2. The Structure of the Electronic Manual

It is worth noting that the Content page of the PDF electronic manual is created automatically by the software and displays the automated content with hyperlinks and page numbering. If there is a need to create your own hyperlinks on topic pages, you have to use the Link button of the Content Editor toolbar to insert the hyperlink. The dialogue box that appears will allow you to link the part of the description text with an external URL or an internal project node, and to remove an unnecessary link. These links are the transition to the distance course that can be made from the front page of the electronic manual.

It is worth emphasizing that it is essential for mobile learning to create electronic teaching aids in the formats supported by mobile devices. Hypertext training materials in the PDF format are popular and affordable today. We recommend using such software as Adobe Acrobat, Adobe Reader, PDFMaster and others to view such electronic manuals (in the PDF format). These programs are easy to install on any computer, laptop, tablet or smartphone, which makes the learning process available anywhere, anytime, and with the use of any device.

Particular stress should be put on the fact that this electronic manual is effective and fully functional in any modern browser: Google Chrome, Opera, Mozilla Firefox, Yandex.Browser, Internet Explorer and others.

It is desirable to organize feedback between a student and a teacher via modern Internet technologies: e-mail, Google services (chat, video conferencing), social networks, Viber, Skype, Telegram, WhatsApp, etc. These services and their scope in terms of interaction today solve the problem of organizing quick feedback with the teacher (correspondence, file sharing, video calls, virtual consultations, etc.).

Therefore, to organize mobile learning at university a teacher has to:

- have (develop) electronic teaching resources in the PDF format (from lectures, practical and individual tasks to entire electronic textbooks, manuals and teaching materials on the discipline);

- give the students access to these materials: post them on their own website, on the social networking site, or on the university's website; 
- communicate with the students in the process of mobile learning (correspondence, file sharing, questions-answers, testing and assessment, etc.).

In order to provide efficient mobile learning, a student has to:

- download electronic teaching materials to their mobile device;

- communicate with the teacher in the process of mobile learning (correspondence, sms-messages, file sharing, questions-answers, etc.);

- have a desire to learn!

In order to ensure the effective functioning of the mobile learning process, sets of electronic teaching materials (the PDF files) have to be developed at the university.

A set of teaching materials for mobile learning has to include:

- guidelines (instructions) on the organization of mobile learning in general and the use of teaching materials;

- lecture summaries on the discipline;

- practical tasks (laboratory practicum);

- individual tasks;

- audio and video lectures (recommended).

In general, mobile learning as a form of resource-based learning enables the transformation of the learning process due to the modern information and communication technologies with an emphasis on Internet technology (Table 1).

Table 1 .

\section{Transformation of the learning process in the context of mobile learning at university}

\begin{tabular}{|c|c|}
\hline \multicolumn{1}{|c|}{ The Class Type } & \multicolumn{2}{c|}{ The Technology Used } \\
\hline \multirow{3}{*}{ Lecture: } & $\checkmark$ a videoconference (combined with a slide show); \\
& $\checkmark$ electronic learning resources (textbooks, manuals, distance \\
& course); \\
& $\checkmark$ audio lectures; \\
& $\checkmark$ video lectures (they are convenient to be located on video \\
& hosting www.youtube.com, cloud services or social \\
& networks).
\end{tabular}




\begin{tabular}{|l|l|}
\hline \multirow{2}{*}{ performing } & $\checkmark$ e-mail; \\
practical tasks & $\checkmark$ mailing list; \\
& \multicolumn{1}{|c|}{ WhatsApp; } \\
& $\checkmark$ the distance course environment. \\
\hline performing & $\checkmark$ conference (video or audio); \\
other types of & $\checkmark$ electronic portfolio of a student; \\
tasks & $\checkmark$ website of a student or a group of students. \\
\hline Knowledge & \\
assessment: & $\checkmark$ e-mail; \\
\hline report on the & $\checkmark$ mailing list; \\
work done or & $\checkmark$ testing systems; \\
the student's & $\checkmark$ website of a student or a group of students; \\
portfolio & $\checkmark$ the distance course environment. \\
\hline credits or & $\checkmark$ testing systems; \\
examinations & $\checkmark$ video conferences; \\
\hline presentation of & $\checkmark$ the distance course environment. \\
individual & $\checkmark$ website of a student or a group of students; \\
educational & $\checkmark$ discussion in social networks, Viber, Skype, Telegram, \\
projects & $\checkmark$ WhatsApp; \\
\hline
\end{tabular}

The organization of mobile learning for students of PUET, Ukraine, has been carried out in the way presented above.

Experimental verification of students' mobile learning effectiveness in the study of the "Fundamentals of Leadership" discipline was carried out in 2018-2019 academic year (educational programs "Business Administration", "Enterprise Economics", "Management", "Tourism", "Local Government", "Public Administration", "Human Resources Management", "Foreign Economic Activity Management", "Banking", "Finance and Credit", "Finance, Banking and Insurance "). In total, 1213 students participated in the experiment. The control group (CG) included 604 students, and the experimental group (EG) - 609 students.

Assessment of students' knowledge was carried out according to the criteria presented in the course syllabus. The students are supposed to know:

- dependence of leadership style on people and situations;

- major differences in leadership and management;

- traditional leaders use traditional leadership methods;

- differences between leadership styles;

- characteristics of the main types of leadership;

- how to motivate people;

- how to delegate authority;

- how to distinguish between dialogue and discussion;

- how to use communication tools to influence others;

- how to create a monolithic team;

- how to help followers maximize their potential;

- core values related to an achievement-oriented culture. 
The results of diagnostics of students' level in the discipline "Leadership" before and after the introduction of mobile learning using the distance course and the online manual "Fundamentals of Leadership" are presented in table 2.

Table 2

Results of diagnostics of students' academic performance in the discipline
"Fundamentals of Leadership" (before and after the experiment)

\begin{tabular}{|c|c|c|c|c|c|c|c|c|}
\hline \multirow{2}{*}{$\begin{array}{c}\text { Levels of } \\
\text { knowledge }\end{array}$} & \multicolumn{4}{|c|}{ Before the experiment } & \multicolumn{4}{c|}{ After the experiment } \\
\cline { 2 - 9 } & \multicolumn{2}{|c|}{ CG } & \multicolumn{2}{|c|}{ EG } & \multicolumn{2}{c|}{ CG } & \multicolumn{2}{|c|}{ EG } \\
\hline low & 127 & $21,03 \%$ & 158 & $25,94 \%$ & 115 & $19,04 \%$ & 23 & $3,78 \%$ \\
\hline average & 349 & $57,78 \%$ & 332 & $54,52 \%$ & 353 & $58,44 \%$ & 369 & $60,59 \%$ \\
\hline high & 128 & $21,19 \%$ & 119 & $19,54 \%$ & 136 & $22,52 \%$ & 217 & $35,63 \%$ \\
\hline
\end{tabular}

The dynamics of changes in students' knowledge levels after the introduction of mobile learning in the discipline "Fundamentals of Leadership" is shown in table 3:

Table 3

\section{Dynamics of changes in students' knowledge levels after mobile learning}

\begin{tabular}{|c|c|c|c|c|}
\hline \multirow{2}{*}{$\begin{array}{c}\text { Levels of } \\
\text { knowledge }\end{array}$} & \multicolumn{4}{|c|}{ Number of students } \\
\cline { 2 - 5 } low & -12 & $-1,99 \%$ & -135 & $-22,16 \%$ \\
\hline average & +4 & $+0,66 \%$ & +37 & $+6,07 \%$ \\
\hline high & +8 & $+1,33 \%$ & +98 & $+16,09 \%$ \\
\hline
\end{tabular}

As shown in Table 3, the number of students with the high level increased in CG by $1.33 \%$, while in the EG by $16.09 \%$; the number of students with the average level increased in the CG by $0.66 \%$, while in the EG by $6.07 \%$; the number of students with the low level in the CG decreased by $1.99 \%$, while in the EG it decreased by $22.16 \%$.

The reliability of the results of the experiment was proved using the Pearson criterion $\chi 2$. A null and alternative hypotheses were formulated to test the differences found in the levels of students' knowledge in control and experimental groups. Thus, according to hypothesis H0, the level of knowledge for the discipline "Fundamentals of Leadership" in CG and EG is not fundamentally different. By hypothesis H1, the level of knowledge for the discipline in $\mathrm{CG}$ and $\mathrm{EG}$ are fundamentally different.

Using the data in Table 2 and the Microsoft Excel spreadsheet, Pearson criterion $\chi 2$ was calculated.

Comparing the obtained values of the Pearson test ( $\chi 2 \mathrm{emp})$ with the critical value of the criterion $(\chi 2$ crit), taking into account the data of statistical processing before and after the experiment, we can draw the following conclusions:

before the experiment: $4.11<7.81$, therefore, EG and CG belong to one general totality; hypothesis $\mathrm{HO}$ is accepted, that is, there was no significant difference in knowledge of the discipline "Fundamentals of Leadership" in EG and CG; 
after the experiment: $80.25>7.81$, therefore, we can reject the null hypothesis and accept the alternative one: significant difference obtained in CG and EG is a consequence of the introduction of mobile learning for the students studying the discipline "Fundamentals of Leadership".

This leads to the conclusion that the implementation of mobile learning in the university educational environment to a greater extent contributed to the formation of students' knowledge systems comprising modern leadership theories, psychological features of leadership, theoretical foundations of effective leadership to command management technologies, management styles, methods of development and improvement of personal management style, practical methods of effective management in risk and uncertainty.

\section{CONCLUSIONS AND PROSPECTS OF FURTHER RESEARCH}

The conducted research has allowed us to arrive at the following conclusions:

- mobile learning is a form of resource-based learning;

- mobile learning provides new quality of training and reflects the trends in the education of a modern student in a most comprehensive way, providing continuous access to information at any time;

- mobile learning contributes to the formation of flexible learning due to the new facilities of mobile telecommunication services to deliver texts, graphic materials and videoconferencing;

- modern didactics undergoes changes in terms of the content of the basic principles of learning in the context of mobile form of resource-based learning and requires the development of electronic educational resources for mobile devices;

- in the context of mobile learning, the principle of guided interactive self-learning becomes the determining factor;

- information and telecommunication technologies and Internet technologies change learning methods in general, transform traditional methods in the context of mobile learning with the help of specific services (e-mail, forums, chats, websites, social networks and others) on the basis of different formats of information representation (hypertext, hypermedia, audio and video, interactive components, virtual practicum tools and others);

- mobile learning makes it possible to organize a high degree of interactivity between a teacher and a student, to provide efficient feedback through mobile devices and to increase the portion of collaborative learning and classroom group learning.

To conclude, it should be noted that the success in the sphere of mobile learning will become more significant over time. The efficiency and public acceptance of this form of learning will increase. Moreover, we optimistically overcome the problems which arise along this path and are solved by joint efforts of higher education institutions and educational authorities. The next issues that are high on the agenda are the following: the coordination and methodological support of mobile learning; the development of a comprehensive approach to the creation of a national educational and scientific information environment of Ukraine, which would include the telecommunication infrastructure, information resources for education and science, networks of electronic libraries, inter-university virtual laboratories; joining the European educational and research networks and information resources; the formation and improvement of teaching support for mobile learning. 


\title{
REFERENCES (TRANSLATED AND TRANSLITERATED)
}

[1] V. Yu. Bykov, Open Learning Environment and Modern Network Tools for Open Education Systems. Scientific Journal of the NPU named after M.P. Drahomanov, Series 2. Computer-oriented systems of training. № 9, pp. 9-15. 2010. (in Ukrainian).

[2] V. Bondar, Didactics. Kyiv : Lybid. 264 p. 2005. (in Ukrainian).

[3] I. N. Golitsyna, N. L. Polovnikova, Mobile Learning as a New Technology in Education. Educational Technology \& Society. № 1. pp. 241-252. 2011. (in Russian).

[4]N. V. Kononets, Didactic Bases of Resource-Based Learning of Computer Disciplines by Students of Agrarian Colleges. (The Diss. of D.Ed.). Poltava. 473 p. 2016. (in Ukrainian).

[5] N. V. Kononets, The Use of Cloud-hosted Computing for Resource-Based Learning of Computer Science.Materiaty IX Międzynarodowej naukowi-praktycznej konferencji «Wykształcenie $i$ nauka bez granic - 2013». Vol. 24. Pedagogiczne nauki: Przemyśl. Nauka i studia. pp. 94-100, 2013. (in Ukrainian).

[6] N. V. Kononets, Social Networks as a Means of Resource-Based Learning of Computer Disciplines at Agrarian Colleges. The Headmaster of a School, Lyceum, Gymnasium. № 1-4. pp. 79-89. 2014. (in Ukrainian).

[7]N. V. Kononets, Dr.Explain as an Effective Means of Creating Electronic Learning Resources for ResourceBased Learning. Computer at School and Home. № 6(118). pp. 35-40. 2014. (in Ukrainian).

[8] V. A. Kuklev, The Formation of the System of Mobile Learning in Open Distance Learning. Abstract of a Dissertation for Obtaining the Degree of Doctor of Education. Ulyanovsk. 46 p. 2010. (in Russian).

[9] V. V. Lapinskyi, The Didactic Requirements for Computer-Oriented Means of Learning. New Technologies of Teaching: a research and methodological collection. Kyiv : The Research and Methodological Center of Higher Education. pp. 104-107. 2004. (in Ukrainian).

[10] O. O. Nestulya, S. I. Nestulya, Fundamentals of Leadership. Scientific Concepts (the middle of XX-the beginning of XXI cent.): a study guide. Poltava : PUET. 375 p. 2016. (in Ukrainian).

[11] O. O. Nestulya, S. I. Nestulya, Fundamentals of Leadership: a study guide. Poltava: RVV PUSCU. 126 p. 2009. (in Ukrainian).

[12] N. V. Rashevska, Mobile Information and Communication Technologies of Teaching Higher Mathematics to Students of Higher Technical Institution. Abstract of a Dissertation for Obtaining the Degree of Candidate of Pedagogical Sciences. Institute of Information Technologies and Learning Tools of the National Academy of Pedagogical Sciences of Ukraine. Kyiv. 21 p. 2011. (in Ukrainian).

[13] I. S. Son, Mobile Teaching in Learning Foreign Languages. Theory and Practice of Education in the Modern World: Materials of the $3^{\text {rd }}$ Internatonal Scientific Conference (Saint Petersburg, May 2013). Saint Petersburg: Renome. pp. 164-167. 2013. (in Russian).

[14] O. V. Spivakovskyi, I. B. Fedorova, O. O. Hlushchenko, N. A. Kudas, Management of Information Technologies of Higher Education: a study guide.The third edition, revised. Kherson: Ailant. 302 p. 2010. (in Ukrainian).

[15] Baiyun Chen, Ryan Seilhamer, Luke Bennett and Sue Bauer, Students' Mobile Learning Practices in Higher Education: A Multi-Year Study, EDUCAUSE Review July/August 2015. (in English).

[16] Ibrahim Suleiman, Abdel Rahman. EDUCATIONAL LEAPFROGGING IN THE MLEARNING TIME. Turkish Online Journal of Distance Education-TOJDE July 2014 ISSN 1302-6488 Volume: 15 Number: 3 Article 1.pp.10-17. (in English).

[17] Kristine Peters, M-Learning: Positioning educators for a mobile, connected future. The International Review of Research in Open and Distributed Learning. Vol 8, No 2. 2007.(in English).

[18] B. Nail, W.A. Ammar, Mobile Learning Education has Become More Accessible. Am J Compt Sci Inform Technol 5: 2. doi: 10.21767/2349-3917.100005. 2017 (in English).

Text of the article was accepted by Editorial Team 10.04.2019

\section{ДОСВІД УПРОВАДЖЕННЯ МОБІЛЬНОГО НАВЧАННЯ СТУДЕНТІВ ОСНОВ ЛІДЕРСТВА ЯК РЕСУРСНО-ОРІЄНТОВАНОЇ ФОРМИ}

\author{
Кононец Наталія Василівна \\ доктор педагогічних наук, доцент кафедри економіки підприємства та економічної кібернетики \\ ВНЗ Укоопспілки «Полтавський університет економіки і торгівлі», м. Полтава, Україна \\ ORCID ID 0000-0002-4384-1198 \\ natalkapoltava7476@gmail.com
}




\title{
Нестуля Світлана Іванівна
}

кандидат історичних наук, доцент кафедри управління персоналом та економіки праці, директорка навчально-наукового інституту лідерства

ВНЗ Укоопспілки «Полтавський університет економіки і торгівлі», м. Полтава, Україна,

ORCID ID 0000-0002-8853-4538

snestulya@gmail.com

\begin{abstract}
Анотація. У статті автори розглядають мобільне навчання як форму ресурсноорієнтованого навчання студентів університету при вивченні дисциплін професійно орієнтованого циклу. Схарактеризовано умови, необхідні для організації мобільного навчання в освітньому середовищі сучасного університету: наявність мобільних пристроїв у студентів та викладачів; наявність розроблених електронних освітніх ресурсів (електронні підручники та посібники, освітні вебсайти, дистанційні курси); організація зворотного зв'язку між викладачем та студентом. На прикладі викладання дисципліни «Основи лідерства» у Вищому навчальному закладі Укоопспілки «Полтавський університет економіки і торгівлі» автори пропонують способи організації мобільного навчання студентів заочно-дистанційної форми навчання в університеті. Запропоновано розроблений дистанційний курс (платформа дистанційного навчання Moodle) та електронний посібник 3 дисципліни «Основи лідерства» для мобільних пристроїв (програма Dr.Explain). Продемонстровано можливості та переваги програми Dr.Explain, яка дозволяє створювати електронні посібники для мобільного навчання. У статті доводиться, що Dr.Explain $\epsilon$ зручним та ефективним засобом для розробки різноманітних електронних освітніх ресурсів, починаючи від електронних конспектів лекцій та посібників і закінчуючи повноцінними електронними навчально-методичними комплексами дисциплін та освітніми Інтернетресурсами. Автори акцентують увагу на тому, що для мобільного навчання необхідно створювати електронні засоби навчання в таких форматах, які підтримуються мобільними девайсами. Популярними і доступними сьогодні $\epsilon$ гіпертекстові навчальні матеріали у форматі PDF. Висвітлено досвід організації мобільного навчання та схарактеризовано особливості трансформації навчального процесу при мобільному навчанні в університеті.
\end{abstract}

Ключові слова: мобільне навчання; ресурсно орієнтоване навчання; дистанційний курс; електронний посібник; лідерство; університет

\section{ОПЫТ ВНЕДРЕНИЯ МОБИЛЬНОГО ОБУЧЕНИЯ СТУДЕНТОВ ОСНОВ ЛИДЕРСТВА КАК РЕСУРСНО-ОРИЕНТИРОВАННОЙ ФОРМЫ}

Кононец Наталья Васильевна

доктор педагогических наук, доцент кафедры экономики предприятия и экономической кибернетики ВУЗ Укоопсоюза «Полтавский университет экономики и торговли», г. Полтава, Украина

ORCID ID 0000-0002-4384-1198

natalkapoltava7476@gmail.com

Нестуля Светлана Ивановна

кандидат исторических наук, доцент кафедры управления персоналом и экономики труда, директор учебно-научного института лидерства

ВУЗ Укоопсоюза «Полтавский университет экономики и торговли», г. Полтава, Украина

ORCID ID 0000-0002-8853-4538

snestulya@gmail.com

Аннотация. В статье авторы рассматривают мобильное обучение как форму ресурсноориентированного обучения студентов университета при изучении дисциплин профессионально ориентированного цикла. Охарактеризованы условия, необходимые для организации мобильного обучения в образовательной среде современного университета: наличие мобильных устройств у студентов и преподавателей; наличие разработанных электронных образовательных ресурсов (электронные учебники и пособия, образовательные сайты, дистанционные курсы); организация обратной связи между преподавателем и студентом. На примере преподавания дисциплины «Основы лидерства» в Высшем учебном заведении Укоопсоюза «Полтавский университет экономики и торговли» авторы предлагают способы организации мобильного обучения студентов заочно- 
дистанционной формы обучения в университете. Предложен разработанный дистанционный курс (платформа дистанционного обучения Moodle) и электронное пособие по дисциплине «Основы лидерства» для мобильных устройств (программа Dr.Explain). Продемонстрированы возможности и преимущества программы Dr.Explain, которая позволяет создавать электронные пособия для мобильного обучения. В статье доказывается, что программа Dr.Explain является удобным и эффективным средством для разработки различных электронных образовательных ресурсов, начиная от электронных конспектов лекций и пособий и заканчивая полноценными электронными учебно-методическими комплексами дисциплин и образовательными Интернет-ресурсами. Авторы акцентируют внимание на том, что для мобильного обучения необходимо создавать электронные средства обучения в форматах, поддерживаемых мобильными девайсами. Популярными и доступными сегодня являются гипертекстовые учебные материалы в формате PDF. Освещен опыт организации мобильного обучения и охарактеризованы особенности трансформации учебного процесса при мобильном обучении в университете.

Ключевые слова: мобильное обучение; ресурсно-ориентированное обучение; дистанционный курс; электронное пособие; лидерство; университет.

\section{(cc) BY-NC-SA}

This work is licensed under Creative Commons Attribution-NonCommercial-ShareAlike 4.0 International License. 